\title{
TÜRK MEDENİ KANUNU İLE AİLE HUKUKUNDA YAPILAN DEĞIŞSIKLIKLER VE BU KONUDA BAZI ÖNERILERIMIZ
}

\author{
Yard. Doç. Dr. Veysel BAŞPINAR*
}

\section{TARIHÇE:}

$1971^{1}$ ve $1984^{2}$ yıllarında hazırlanan ikj ayrı Medeni Kanun tasarısı yürürlüiğe girememiştir. Adalet Bakanlığı tarafından 1996 yılında, Medeni Kanun Tasarısını hazırlamak üzere yeni bir komisyon kurulmuştur. Söz konusu komisyon bugünkü Medeni Kanun'un ilk tasarısını hazırlamış ve bu tasarı 1998 yılında Adalet Bakanlığı tarafından yayınlanmıştır'. Ancak Tasarıda yasal mal rejimi olarak yer alan "Paylaşmalı Mal Ayrılığı", 1999 yılında Komisyon tarafından "Edinilmiş Mallara Katılma Rejimi" olarak değiştirilmiştir. Böylece Medeni Kanun 1999 Tasarısı ortaya çıkmıştır. 01.01.2002 tarihinde yürürlüğe giren 4721 sayılı Türk Medeni Kanunu işte bu son tasarı metnidir".

1 Ocak 2002 tarihinde yürürlüğge giren Türk Medeni Kanunu ile, eski Medeni Kanun'un, gerek şekil gerek içerik bakımından pek çok hükmünde

* Ankara Üniversitesi Hukuk Fakültesi Medeni Hukuk Anabilim Dałı Öğretim Ùyesi

' Bkz. Adalet Bakanlığı, Türk Medeni Kanunu Ön Tasarısı ve Gerekçesi. Adı geçen komisyonun, çeşitli kurumlarında Medeni Kanun'un dilini sadeleştirmeden ve doktrinde ileri sürülen mevcut eksiklik ve yanlışlıkları düzeltmeden öteye gidemediği ileri sürülmektedir. $\mathrm{Bu}$ konuda geniş bitgi için bkz. Özsunay, Ergun: Medeni Hukuka Giriş, 5. Bası, İstanbul 1986. sh. 162-163.

${ }^{2}$ Adalet Bakanlığı, Türk Medeni Kanunu Öntasarısı ve Gerekçesi, Ankasa 1984.

${ }^{3}$ Adalet Bakanlığı Tarafından Hazırlanan Türk Medeni Kanunu Tasarısı ve Gerekçesi. Ankara 1998.

4 Tasarı TBMM Genel Kurulanda birkaç maddede yapılan değişiklikler hariç, komisyondan geldiği şekliyle aynen kabul edilmiştir. Genel Kurulda değişikliğe uğrayan maddeler şunlardır: $78,274,289,463,465,559,571,707,851,970$. 
değişiklik yapılmıştır". Şekle ilişkin değişiklikler arasında ilk sırada madde numaraları gelmektedir". Ayrica yeni diizenlemede bölüm numaraları da eski metinden farklıdır ${ }^{7}$. Yeni metinde ayrıca çok fazla kavram de ğ̣işikliği yer almaktadır.

Yeni Kanun'un içeriği de eski hükümlerden son derece farklılık arzetmektedir. Oysa, gerek medyada gerek kamu oyunda, yeni Kanun'daki en önemli değişikliğin, evlilikte eşler arasındaki mal rejimlerinde yapıldığı intibaı uyandırılmıştır". Kısaca, kamuoyunda: yeni Türk Medeni Kanunu ile. eski Kanın hükümlerinde yapılan değişikliğin, yeni bir mal rejiminin kabul edilmesinden ibaret olduğa kanaati doğmuştur.

Doktrinde bir görüş ise, değişikliklerin önemini vurgulamak için, Türk Medeni Kanunu'nu bir devrim kanunu olarak nitelendirmiştir".

Kanun metni yakından incelendiği takdirde, değişikliğin kamuoyundaki algılandığı kadar basit olmadığ açıkça görülmektedir. Gerçekten de yeni Kanunla getirilen değişiklikler yalnız mal rejimi ile smırlı değildir. Yeni Medeni Kanunda, başlangı̧ hükümlerinden itibaren, zilyetlik ve tapu siciline kadar, eski Medeni Kanun hükümlerinde son derece önemli deģişiklikler kabul edilmiş̧ir. Bu deģişikliklerin hepsinin ayrnntılı bir şekilde ele alınması, bu çalışmanın boyutunun çok üzerindedir ${ }^{10}$. Bu nedenle, aşağıda yeni Kanunla getirilen değişikliklerden sadece aile hukukundaki diizenlemeler kısaca ele alınmıştır.

'Bk\%. Adalet Bakanlığı; Türk Medeni Kanunu, Türk Medeni Kanınunun Yürürlüğü ve Uygulama Şckli Hakkında Kanun ve Gerekçeleri. Ankara 2002 (Bundaı boyle Gerekçc olarak anılacaktır). Türk Medeni Kanunu ile eski Medeni Kanun hüikümlerinde yapılan değişiklikletc toplu bir bakış ve ayrıntılı bilgi için bk7. Kılı̨̧oğglu. Ahmet: Medeni Kanun 'umuzun Aik-Miras-Ȩ̧ya Hukukuna Getirdið̌i Yenilikler. Ankara 2003. sh. I vd.

"Madde nuınaralatımn değiştirilmeșinin gerekçeleri konusunda ayrıntılı bilga için bk\%. Gerekçe, sh. 286-287.

${ }^{7}$ Türk Modeni Kanunu'ndaki şekle ilişkin diğer değişiklikler için bkz. Gerehçe, sh. 287 289.

${ }^{*}$ Bu konudá geniş bilgi için bkz. Kılıçoğlu. Ahmet: Eşler Arasında Yaısal Mal Rẹimi ve Yeni Bir Öneri. Yargtay ın 128. Ankara Üniversitesinin 50. ve Ankara Hukuk Fakültesi’nin 75. Kuruluş Yıldönümi Sempozyumu, (aşağıda Kılıçoğlu Öneri olarak anılacaklır), Ankara 1996. sh. 19 vd.

"Şahin. Şaziye; Yeni Medeni Kanun Kadın Hakları Açısından Ne Getirdi?. Attalya Barosu Dergisi, Ocak: 2002, sh. 12 vd.

"Hața. Medeni Kanun'un bir bölümünde yapılan değjşiklikler, bağımsı bir kitap oluşturacak kadar fazla olabilmektedir. Meselâ bkz. Sungurbey. İsmet; Medeni Kanun Öntasarısını Nesneler Hukukunun Eleştirisi. Ístanbul 1972. 
Türk Medeni Kanunu'nda, eşitlik ilkesine uygun olarak kadının yerleşim yerinin, kocanın yerleşim yerine bağlanması esası terkedilmiştir ${ }^{\mathrm{t}}$. Ayrıca, TMK. m. 21/I'de velayet altındaki çocuğun yerleşim yeri ile ilgili olarak "Velâyet altında bulunan çocuğun yerleşim yeri, ana babasının; ana ve babanın ortak yerleşim yeri yoksa, çocuğun kendisine bırakıldığı ana veya babanın yerleşim yeridir. Diğer hallerde çocuğun oturma yeri, onun yerleşim yeri sayılır" hükmü yer almaktadır' ${ }^{12}$. Bu dïzenlemeler, Birleşmiş Milletler tarafından 18.12.1979 tarihinde kabul edilen "Kadılara Karşı Her Türlü Ayrımcılığın Önlenmesi Uluslararası Sözleşmesi"ne ${ }^{13}$ uygundur. Getçekten de, adı geçen sözleşme m. 15/b. 4'te "Taraf Devletler, kadın ve erkeğe hukukî olarak yerleşme yeri seçme ve nakletmede eşit yasal haklar tanıyacaklardır." hükmü yer almaktadır.

\section{TÜRK MEDENİ KANUNU ILE AİLE HUKUKUNDA GETİRI- LEN DEĞIŞİKLÍKLER}

\section{A. Nişanlanma}

1998 Tasarısında nişanlanma, önce sözleşme ${ }^{14}$ olarak nitelendirilmiş, ancak Kanunda bu durum düzeltilmiştir (TMK. m. 118/II). TMK. m. 120 ve devamında, nişanlılı̆̆ın sona ermesi sebebiyle dava açılması halleri genişletilmiştir. Çünkü Kanunda "Nişanlılardan biri haklı bir sebep olmaksızın nişanı bozduğu veya nişan taraflardan birine yükletilebilen bir sebeple bozulduğu takdirde" (TMK. m. 120/I) ve "nişanlılı̆̆ın sona ermesinden doğan dava hakları" ifadesi yer almaktadır ${ }^{15}$. Her ne kadar, genel gerekçenin söz konusu madde ile ilgili kısmında "Böylece madde, nişanlılığın sadece bozulması hâlini değil, fakat ölüm ve gaiplik gibi diğer sona erme sebeplerini de kapsayacak biçimde kaleme alınmıştır" ${ }^{\prime 16}$ ifadesi

" Eski Medeni Kanunda "Kocasın ikametgahı karının.... ikametgahı addolunur" hükmü yer almaktaydı (eMK. m. 21).

12 Kanımızca bu ifade, "ana ve babanın ortak bir yerleşim yeri olmaması durumunda. çocuğun yerleşim yeri, velayeti veya bakımı kendisine bırakılan tarafın yerleşim yeridir" şeklinde olmalıydı.

${ }^{13}$ Kadınlara Karşı Her Türlü Ayrımcılığın Önlenmesi Uluslararası Sözleşmesi, (aşağıa "Sözleşme"olarak anılaçaktır). Adı geçen sözleşme. TBMM tarafından 11.06 .1985 tarih ve 3232 sayılı "Kadınlara Karşı Her Türlü Ayrımcılığın Önlenmesine Katılmanın Uygun Bulunduğuna Dair Kanun”la kabul edilniştir. (RG. T. 25.06.1985, S. 18792).

14 Nişanlamanın hukuki niteliği konusundaki tartı̧̧malar ve geniş bilgi için bkz. Koç, Nevzat; Türk-Isviçre Hukukunda Nişanlanma Sözleşmesi, İzmir 2002. sh. 13 vd.

${ }^{15} \mathrm{Bkz}$. Gerekçe, sl]. 362.

${ }^{16} \mathrm{Bkz}$. Gerekçe, sh. 293. Bu konuda ayrıntılı bilgi için bkz. Gezici, Sevim/Kalkan. Burcu; Aenderungen innerhalb des Eheschliessungsrechts im türkischen Zivilrecht, Annales de la Faculté de Droit d'Istanbul, Volume 34, No: 51 (2002), sh. 281 vd. 
yer almakta ise de, kanımızca ölüm ve gaiplik hallerini ayrı tutmak gerekir. Zira, ölüm ve gaiplik hallerinde ancak hediyelerin iadesi davası açılıp, diğer davalar açılamaz ${ }^{17}$. Bu davaların açılması bakımından kadın veya erkek ayrımı söz konusu değildis ${ }^{13}$.

\section{B. Evlenme}

Yeni Medeni Kanunda evlenme yaşı kadın ve erkek için 17 olarak belirlenmiştir (TMK. m. 124/1). Bunun için 17 yaşın tamamlanması yani 18 . yaştan gün alınması gerekmektedir ${ }^{19}$. Buna karşıllık, olağanüstü evlenme yaş̧ı ise, cinsiyet ayrımı yapılmadan 16 olarak belirlenmiştir (TMK. m. 124/I1) ${ }^{241}$.

Akıl hastalarının asla evlenemeyeceğine dair hüküm (cMK. m. 89/II) yeni Medeni Kanunda değiştirilmiştir. Yeni Medeni Kanunda, "aǩl hastaları

${ }^{17}$ Geniş bilgi için bk7. Koç. sh.74-75, 139-140.

${ }^{1 *}$ Sözleşmenin 16. maddesinin 1. fikrasında taraf devletlerin, kadınlara karşı evlilik ve aile ilişkileri konusunda ayrımı önlemek için gerekli bütün önlemleri alacakları ifade edilmiştir. Ayrıca bkz. Kılı̧̧oğlu, Yenilikler, sh. 3 vd.

$1 \%$ Zevkliler, A./Havuţ̧u, A.: Yeni Medeni Kanuna Göre Medeni Hukuk (Temei Bilgiler). Ankara 2002, sh. 226: Akıntirk, Yeni Medeni Kanuna Uyarlanmıs Aile Hukuku. 6. Bası, 1stanbul 2002, sh. 60 .

2" Bkz. Kılıçoğlu, Yenilikler, sh.5. Kanunlar hazırlanırken belirli ilkelere de uymak gerekir. Bunlardan bazıları kanunlar hazırlanırken sosyal ve psikolojik taktörlerin göz ardı edilmemesi, uygulamayı toplumun kaldırıp kaldırmayacağının belirlenmesi, kanuna uyumu etkileyen faktörlerin çeşitliliğinin değerlendiriłmesi ve aşır zorlayı m mueyyidelere ycr verilmemesidit. Geniş bilgi için bkz. Em. Ali; Kanunların ve İdari Tasarrujların Yapm Tckniği. Ankara 1998, sh. 9 vd. Yukarıdaki hükmü sevkedenler, evlenme yaşı ile ilg̣ili ülkemizdcki geçmiş tecrübeleri unutmuş görünmektedirler. Nitekim Medeni Kånunummuzun iktibas edilerek yürürlüğc konulduğu tarihlerde, kadınlar için böyle bir yaş hidddi (17 yaşı) öngörülmiısş idi. Ancak, ülkemizde özellikle kırsa] bölgelerde kızlatı erken yaşlarda evlendirme geleneği bugün dahi mevcuttur. Bunun sonucu olarak, yaş küçük'jiğüu scbebiyle birçok gayrimeşru evlilikler olmuştur. Bu ilişkiden ise daha çok, erken yaşta culenen kadıular ile böyle hir evlilikten doğan çocuklar zarar görmüştïr. Bu sosyal gerçeklik katıun koyucuyu evlenme yaşımı indirmeye zorlamıştır. Geniş bilgi için bkz. Akıntürk. Turģut: Aile Hukuku. 4. Bası, Ankara 1996, sh. 59 vd; Edis, Seyfullah; Medeni Hukuka Giriş ve Başlanģıç Hüküimleri, 4. Bası, Ankara 1989. sh. 107. Atatürk zamanında kadınlar ve çocuklar için bu sakıncalı duruma son verilmiştir. Bu amaçla 1938 yılında 3453 sayılı Kanunla culenme yaşı düşürülmüş̧tïr. Böylece evlenme yaşı kadınlar için 15, erkekler için 17 olárak belirlemiștir. Evlenme yaşııın indirilmessinin yerinde olmadığı konusunda görüş için bkz. Arık, Kenai Fikret; Medeni Kanun ve Yapılan Bazı Tenkitler. SBFD. 1963, S, 1, sh. 207. Isviçre hukukunda da rüşı ve evlenme yaşı 1 Ocak 2000 tarihinden itibaren 18 olarak belirlenmiştir. Bkz. ZGB. Art. 14, 94. 
evlenmelerinde tıbbi sakınca bulunmadığı resmî sağlık kurulu raporuyla anlaşılmadıkça evlenemezler" hükmü yer almaktadır (TMK. m. 133) ${ }^{21}$.

Yeni düzenlemede, yasal temsilcinin evlenmeye izin verme konusundaki yetkisini kötüye kullanması halinde, talepte bulunan küçüiğün mahkemeye başvurarak hâkimden izin alınması imkânı getirilmiştir (TMK. m.128) ${ }^{22}$.

\section{Evliliğin genel hükümleri}

Yeni metinde evliliğin genel hükümleri ile ilgili olarak, eski Medeni Kanun'dan çok farklı düzenlemelere yer verilmiştir. Bununla birlikte söz konusu deģişikliklerin çoğunun, kadın-erkek eşitliğini gerçekleştirmeye yönelik hükümler olduğunu söylemek mümkündür. Bunlar arasmda evlilik birliğinin temsili, evlilik birliğinin beraberce yönetilmesi, eşlere, birliğin giderlerine yalnız malvarlığı ile değil emekleriyle de katılabilme imkânının sağlanmıs olması ${ }^{23}$, oturulacak konutun birlikte seçilmesi, üçüncỉ kişilere karşı sorumluluk, eşlerin meslek ve işi, aile konutu, evlilik birlił̆inin giderlerine katılma ilk sırada sayılabilir ${ }^{24}$.

\section{Boşanma ve ayrılık}

İsviçre hukukunda boşanma sebepleri, 01.01.2000 tarihinden geçerli olmak üzere değiştirilmiştir. Buna göre İsviçre'de boşanma sebeplerini, özel boşanma sebepleri ve genel boşanma sebebi olmak üzere ikiye ayırma geleneği terkedilmiştir ${ }^{25}$. Buna karşılık, Türk Medeni Kanunu'nda boşanma

${ }^{21}$ Gerekçede söz konusu hüküm ile ilgili olarak, bazı akıl hastalarının tedavi sonucu iyileşebilecekleri belirtilmiştir. Bu sebeple söz konusu kimselerin hepsinin aynı düzenlemeye tabi olmaları isabetti bulunmamıştır. Bu konuda geniş bilgi için bkz. Gerekçe. sh. 366-367; Kılıçoğlu. Yenilikler. sh. 7. Mesela melankoli hastalığı sürekli bir nitelik taşımamaktadır. Ayrıntılı bilgi için bkz. Gezici/Kalkan, sh. 288.

${ }^{22}$ Eski Medeni Kanunda bulunmayan bu maddenin gerekçesinde, kanuni temsilcinin özellikle kız kaçırma ve kocaya kaçma gibi olaylar yüzünder aileler arasında kavgalara sebebiyet verecek sonuçlatın önleımesinin amaçlandığı ifade edilmiştir. Bkz. Gerekçe, sh. 365; Aktntürk, sh. 65; Özdamar, sh. 223.

${ }^{23}$ Ayrıntılı bilgi için bkz. Kılıçoğlu, Yenilikler, sh. 25 vd.

${ }^{24}$ Evliliğin genel hủkümlerinde yapılan diłer değişiklikler için bkz. Gerekçc, sh. 296 298; Akıntürk, sh. 103 vd; Gençcan. Ömer Uð̆ur; 4721 sayılı Türk Medeni Kanununa Göre Evliliğin Genel Hükümleri, YD. 2003, S. 1-2, sh. 43 vd.

${ }_{25}^{5 k z}$. ZGB. Art. 111-116. Ísviçre'de boşanma sebepleri konusunda geniş bilgi için bkz. Reusser, Ruth: "Die Scheidungsgründe und die Ehetrennung., in: Vom alten zum neuen Scheidungsrecht, Bern 1999, sh. 10 vd.: Helvacı, Serap: lsviçre ve Türk Hukuklarında Boşanma Sebepleri, Prof. Dr. Ömer Teoman'a 55. Yaş Günü Armağanı, C. II, İstanbuł 2002. sh. 1151 vd; Temel, Erhan; Ehescheidung, Insbesondere wegen Ehebruchs, nach türkischem 
sebepleri, eski Medeni Kanunda olduğu gibi, özel sebepler ve genel sebepler olmak üzere ikiye ayrılmaktadır (TMK. m. 161-166). Ayrıca özel boşanma sebeplerinden hayata kast ve pek kötü davranışın düzenlendiğ̣i TKM. m. 162'ye, "ağ̀r derecede onur kurıcı davranış (=schwere Ehrenkraenkung) ?to" uçüncü bir sebep olarak eklenmiştir ${ }^{27}$. Öte yandan TMK. m. 163'te düzenlenen suç işleme sebebiyle boşanmanın gerçekleşebilmesi için, bunun, diğer eş için çekilmez olması gerekmektedir. Başka bir deyişle, burada bir eşin yalnız suç işlemiş olması yeterli olmayıp, bunun diğer eş için çekilmezlik şartının da gerçekleşmesi aranmaktadır.

Terk (Verlassung=Abandon ${ }^{26}$ sebebiyle boşanmada eMK. m. $132{ }^{\circ}$ de yer akan üç aylık süre, yeni düzenlemede altı aya çıkarılmuştır (TKM. m. 164/I). Sürenin altı aya çkarılmasındaki amaç, eşlerin barışma ümitlerini uzatabilmek ve onlara daha uzun süre disşünme frrsatı vermekti ${ }^{29}$. Bu süre ile, özellikle, pek önemli olmayan sebeplerle ortak konutu terk eden eşlerin, zaman geçtikçe yapıkları davranışın doğru olmadığını anlayarak, telafisi mümkün olmayacak hataya düşmeleri önlenmiş olacağı ifade edilmişti ${ }^{30}$. Ayrıca terk sebebiyle boşanma davasında eski hükümden farklı olarak, intarla iki ay içinde ortak konuta dönmesi imkânı getirilmiştir. Buna göre, terekeden eşe, dördüncü ayın sonunda ihtarda bulunularak, iki ay içinde ortak konuta dönmesi gerektiği hususunda uyarılacaktır ${ }^{3}$. Yeni diizenlemeye göre, ihtar gerektiğginde ilân yoluyla da yapılabilir (TMK. m. 164/I1) (T. $^{32}$.

Yeni düzenteme ile (TMK. m. 199) hâkime, evliliğin devamı veya boşanma sırasında özel önlem alma yetkisi de verilmiştir. Buna göre hâkim,

und schwcizerischem Recht, unter besonderer Berücksichtigung der Entschcidungen des türkischen Kassationsgerichtshofs und des scheweizerischen Bundesgerichts. Prof. Dr. Ömer Teoman'a 55. Yaş Günü Armağanı. C. II, İstanbu! 2002, sh. 1 ]4 I, özellikle sh. 1152 vd.

${ }^{\$ 6}$ Ağır onur kırıcı davranış hakkında ayrıntıłı bilgi için bkz. Tutumlu. M. Akif; Yeni Türk Medeni Kanunu Hükümlerine Göre Evliliğin Butlanı Boşanma. Ayrılık Sebepleri ve Boşanmanın Hukuki Sonuçları, Ankara 2002, sh. 162 vd.

${ }^{27}$ Getckȩede bu sebebin ZGB. Art. 138 'de yer aldığı halde, eski Medeni Kánuna neden alınmadığının belli olmadığı, de ğişikle bu eksikliğin ortadan kaldırıldığı belirtilmiştir. Bkz. sh. 372-373. Ayrıa bk\%. Kılıçoğlu, Yenilikler, sh. 11-12. Oysa ZGB'de 1998 yılunda yăılan değişiklikle diđ̆er scbeplerle birlikte onur kırıci davranıs da boşanma sebebi olnaktan çıkarılmışır. Gerçekten de. boşanma sebeplerinin yer aldığı ZGB Ant. 1 11-IItida onun kırıcı davranıs (Elirenkraekung) yer almamaktadır.

${ }^{2 *}$ Terk sebebiylc konusunda geniş bilg̣i için bkz. Tutumlu, sh. 196 vd.: Kılıçoğlu, Yenilikier, sh. 12; Ehescheidung: Die Krise. www.jurathek de: Wann kann cinc Schciclung aus Härtegründen verweigert werden? www jurathek de: Die Durchfühtung der Ttennung. Wuw juratlick de

${ }^{*}$ Akintiurk, sh. 247; Özdamar, sh. 359.

"Gerekçe, sh. 295, 373.

"Gerckçe.sh. 295.

${ }^{32}$ Bu konuda geniş bilgi için bkz. Akıntürk, sh. 247 vd ; Özdamar. sh. 359; Tutumlu. sh. $219 \mathrm{vd}$. 
evlilik devam ederken veya birlikte yaşamaya ara verilmesi halinde, ortak konuttan ve ev eşyasından kimin yararlanacağına karar verecek ve bu konuda gereken önlemleri alacaktır (TMK. m. 197/II). Hâkim, önlem olarak, eşlerden birinin tasarruf yetkisinin kısıtlanmasına da karar verebilecektir. Aynı şekilde hâkim, eşlerden birinin taşınmazlarıyla ilgili tasarruf yetkisinin smırlanması amacıyla tapuya şerh verilmesine re'sen karar verebilir (TMK. m. 199/III). Bu son durum hâkkimin alacağı önlemlerin özel bir şeklidir ${ }^{33}$. Doktrinde hükmün özel amacının, boşanmaya kararlı olan kocanın, sırf kadına nafaka veya tazminat ödememek için, mallarını başkalarına devretme yolunu kapatmak olduğu ileri sürülmüş̧ür. Bu görüş̧i savunan yazara göre ${ }^{34}$, söz konusu hükümle, dolaylı olarak kadın korunmaktadır. Gerekçede de hükmün, özellikle kocanın, karısından mal kaçırmasını önlemeye yönelik olduğu ifade edilmiştir ${ }^{35}$. Kanımızca, böyle bir hüküm, sadece koca açısından değil, her iki eş açısından da eşlerin birbirilerinden mal kaçırma yolunu kapatmaya yöneliktir. Bu sonuç eşitlik ilkesine de uygundur.

Yeni dỉzenlemede boşanma ve ayrılık davalarında yetkili mahkeme, eşlerden birinin yerleşim yeri veya eşlerin davadan önce, son altı aydan beri oturdukları yer mahkemesidir (TMK. m. 168). Bu sonuç, kadın erkek eşitliğine uygun bir düzenlemedir ${ }^{36}$. Öte yandan, boşanma sebebiyle açlacak davaların, boşanma hükmünün kesinleşmesinden itibaren bir yıl geçmekle zamanaşımına uğraması esası kabul edilmiştir (TMK. m. 178). Eski düzenlemede böyle bir hüküm mevcut değildi. Söz konusu hüküm ile eşlerin, evliliğin son bulmasından yıllar sonra maddi veya manevi tazminat davası ya da yoksulluk nafakası talebiyle karşılaşmalärı önlenmek istenmiştir ${ }^{37}$. Yeni düzenlemede boşanma sonucunda maddi ve manevi tazminat konusunda da bazı değişiklikler yapılmıştır. Buna göre davacının kusursuz olması ortadan kaIdırılmış, davalı tarafın kusurlu olmașı yeterli sayılmıştır ${ }^{38}$.

\section{E. Nafaka}

Yeni Kanunla aile hukuku alanında getirilen bir değişiklik de, boşanma sonunda hükmedilen yoksulluk nafakası ile ilgilidir ${ }^{39}$. Eski Medeni Kanun'da yoksulluk nafakası ödeyen genellikle erkekti. Zira, eMK. m.

\footnotetext{
${ }^{33}$ Aynntılı bilgi jçin bkz. Gerekçe, sh. 384-385: Tutumlu, sh. 418.

${ }^{34}$ Özdamar, sh. 369.

${ }^{35}$ Gerekçe, sh. 384-385.

is Akıntürk. sh. 271.

${ }^{37}$ Gerekçe, sh. 377.

${ }^{3 *}$ Yeni Medeni Kanunda boșanma halinde maddi ve manevi tazminat jle ilgili geniş bilgi için bkz. Kılıçoğlu, Mustafa; 4721 sayılı Yeni Türk Medeni Kanunu'na Göre Boşanma Halinde Maddi ve Manevi Tazminat. ABD. 2002, S. 2, sh. 39, özellikle sh. 41 vd.

${ }^{34}$ Türk Medeni Kanunu ile yoksulluk nafakasi konusunda getirilen yenilikler hakkında ayrıntılı bilgi için bkz. Ruhi, Ahmet Cemal; Tủrk Hukukunda Nafaka ve Nafaka Alacaktarını Yabanct Olkelerde Tahsili, Ankara 2003, sh. 69 vd.
} 
144'de "Erkeğin kadından yoksulluk nafakası isteyebilmesi için kadının hali refahta bulunması gerekir"di. Yeni Kanun, kadın erkek eşitliğine uygun bir düzenleme ile bu şartı kaldırmıştır (TMK. m. 175) ${ }^{40}$. Buna göre, gerek erkek gerek kadın, refah halinde olup olmadıklarına bakılmaksızın, yoksutluğa düşecek olan diğer tarafa yoksulluk nafakası ödemek zorundadır.

TMK. m. 175 hükmüne göre, yoksulluk nafakası için talepte bulunanın kusuru daha ağ yüzünden yoksulluğa düşme tehlikesi bulunmalıdır. Ayrıca hâkimin takdir edeceği nafaka miktarı, diğer eşin mali gücii ile sınıll olacaktır ${ }^{4 !}$. Yeni diizenlemeye göre, boşanmadan sonra açılacak nafaka davalarmnda yetkili mahkeme, nafaka alacaklısının yerleşim yeri mahkemesidir (TMK. m. 177). Söz konusu huikümle nafaka alacaklısı zor durumdan biraz da olsa kurtarilmıştır ${ }^{42}$.

\section{F. Evlilikte mal rejimi}

\section{1) Genel olarak}

Aile hukukunda yapılan en önemli değişiklik ise; eşler arasındaki mal rejiminin değiştirilmesidir ${ }^{43}$. Gerçekten de, eski Medeni Kanun'da eşler arasındaki yasal mal rejimi mal ayrılığı idi. 1998 Tasarısı ile yasal mal rejimi "Paylaşmalı Mal Ayrılığı" olarak belirlenmişti (m. 202) 1999 Tasarısında, İsviçre hukukunda 1988 yılında kabul edilen "edinilmiş

*t Kılıçoğlu. Yenilikler, sls. 19.

${ }^{{ }^{+1}}$ Gcniş bilgi için bkz. Gerekçe, sh. 376: Akıntürk, sh. 294 vd.

${ }^{ \pm 2}$ Kılıçoğlu, Yenilikler, sh. 19.

${ }^{43} \mathrm{Bu}$ konuda geniş bilgi için bkz. KıhçoğJu, Ahmet; Edinilmiş Mallara Katılma Rejimi (bundån böyle Kılı̨̧oğlu Rejim olarak anılacaktır), 2. Bası, Ankara 2002, sh. 8 vd; Ceylan. Ebru, 4721 sayılı Türk Medeni Kanunu`nun Mal Rejimleri ile IIlgili Getirdiği Yeni Düzenlemeler, Prof. Dr. Ömer Teoman'a 55. Yaş Günü Armağant, C. I], İstanbui 2002, sh. 1019 vd; Ačabey, M. Beşir: Evlilik Birliğinde Yasal Mal Rejimi, jzmir 1998, sh. 5 vd.: Şıpka, Şükran Taman; Türk Aile Hukukunda Karı Koca Mal Rejimleri Sisteminde Yapılmak İstenen Düzenlemeler Hakkında Düşünceler. Prof. Dr. Hayri Domaniç’e Armağan. İstanbul 1995. sh. 353 vd; Acabey. M. Beşir; Medeni Kanun Tasarısının Evlilik Birliğginde Yasal Mal Rejimine İiş̧kin Hükumlerinin Değerlendirilmesi. Prof. Dr. Hayri Domaniç'c 80 . Yaş Günü Armağanı. C. II. Istanbul 2001 , sh. $780 \mathrm{vd}$.

${ }^{44}$ Hatta, o dönemde bir makalede, bugün kanuni rejin olan "Edinilmiş Mallara Katılına (=Erungenschaftsbcteiligung)" rejiminin neden ïlkemize uymayacağ ayrıntılı olarak dile getirilmişti. Bhz. Kılıçoğlu. Öneri, sh. 41. Ayn şekilde 1998 Tásarısında codinilmiş mallara katılma rejimi için şu ifadelere yer verilmişti: "Çok karmaşı bir sistem ve evlitiğı̉n sona ermesinde son derece güç bir tasfiye yöntemi öngören bu rejim ayrıntılı bir şekilde incelenmiş ve ülkemiz şartlarına uymadı ğı kanısına varılarak ancak sözjeşmeli (akdî) mai rejini olarak dïzenlenmesi ...sonucuna varilmıştır.” Bkz. 1998 Tasansı m. 232 gerekçesi. 
mallara katılma" rejiminin, ülkemizde de yasal mal rejimi olarak kabul edildiği belirtilmiş, daha sonra bu hüküm kanun metninde de aynen kabul edilmiştir ${ }^{45}$.

Yeni Medeni Kanun, mal rejimi konusunda ikili bir ayrım yapmıştır. Bunlardan birincisi yasal mal rejimi, ikincisi ise seçimlik (akdî) mal rejimidir. Medeni Kanuna göre, yasal mal rejimi "edinilmiş mallara katılma rejimi"dir (TMK. m. 202). Seçimlik mal rejimleri ise, mal ayrılı̆̆ı rejimi (TMK. m. 242-243); paylaşmalı mal ayrılığı rejimi (TMK. m. 244-255) ve mal ortaklığı rejimidir (TMK. m. 256-281). Buna karşılık, yeni düzenlemede, eski Medeni Kanunda yer alan "mal birliği rejimi" (eMK. m. 191-210) kabul edilmemiştir ${ }^{46}$.

Kanunda (TMK. m. 206 vd.) ve doktrinde bir de "olağanüstü mal rejiminden (ausserordentlicher Güterstand)" söZ edilmektedir ${ }^{47}$. Bundan amaç, eşler arasındaki paylaşmalı mal ayrılığı rejiminin veya mal ortaklığı rejiminin, eşlerden birinin talebi veya hakkında cebri icra takibi yapılmasi halinde (yani iflâsta, TMK. m. 209 ya da hacizde TMK. m. 210), kendiliğinden ya da hâkim kararı ile mal ayrılığı rejimine dönüşmesi/ dönüştürülmesidir. Bu şekilde oluşan mal rejimine olağanüstü mal rejimi adı verilmektedir ${ }^{48}$.

Doktrinde bir görüiş, mal rejimi konusunda sözleşme özgürlügünden söz etmektedir ${ }^{49}$. Kanımızca burada sözleşme özguirlüß̆̈̈̈nden değil, sınırlı sayı ve tipe bağlilıktan söz etmek gerekir. Gerçekten de eski Medeni Kanun döneminde olduğu gibi, yeni düzenlemede de eşler, ancak Kanunda öngörülen, olağan (yasal) mal rejimini veya seçimlik mal rejimlerinden birini seçebilirler. Başka bir deyişle, eşler, mal rejimi konusunda ancak kanunda kabul edilen tiplerden birini tercih edebilirler. Çünkü, Kanunda seçilebilecek üç mal rejimi kabul edilmiştir. Ayn şekilde seçilebilen mal rejiminin kanundaki smırlarının değiştirilmesi de mümkün değildir. Ủstelik eşler, bir araya gelerek yeni bir mal rejimi yaratamazlar. Yine eşler, başka bir ülkede kabul edilmiş mal rejimini gerek bütün gerek karma olarak

45 Bkz. Gerekçe, sh. 386. Edinilmiş mallara katılma rejimi konusunda geniş bilggi için bikz Kıłıçoğlu Rejim, sh. 8 vd.; Özdamar, sh. 301 vd.; Acabey, sh. 37 vd; Gençcan, Ömer Uğur; 472 t saytlı Türk Medeni Kanununa Göre Mal Rejimine lisşkin Genel Hükümler ve Edinilmiş Mallara Katıtma Rejimi, Ankara 2002, sh, 73 vd, Moroğlu, Nazan; Medent Kanun'da Mal Rejimleri, İstanbul 2002, sh. 13 vd.

th Özdamar, sh. 313.

27 $\mathrm{Bu}$ kurumun düzenlenmesinde ZGB. Art. 185-192 hükümlerinden geniş ölçüde yararlanılımıştır. Bkz. Gerekçe, sh. 387-389.

${ }^{48}$ Geniş bilgi ve uygulama için bkz. Gençcan, sh. 56 vd; Akıntürk, sh. 138 vd.

${ }^{49}$ Bkz. Kılıçoğlu, Rejim, sh. 28. 
sözleşmeyle benimseyemezler". Bu durum TMK. m. 203'te "taraflar istedikleri mal rejimini ancak kanunda yazılı smırlar içinde seçebilir, kaldırabilir veya değiştirebilir" şeklinde ifade edilmiştir ${ }^{51}$. O halde buradaki özgürlük, sözleşme özgürlüğ̈ değil, üç mal rejiminden birisini seçme özgürlüğünden öteye bir anlam taşımamaktadir ${ }^{52}$. Bu nedenle, mal rejimi konusunda borçlar hukukunda yer alan (BK. m. 19-20) gerçek ve reknik anlamda bir sözleşme özgürliugŭünden söz etmek mümkün değildir ${ }^{53}$.

Eski Medeni Kanunda olduğu gibi (eMK. m. 171), yeni düzenlemeye göre eşler, mal rejimi sözleşmesini, evlenmede önce veya sonra yapabilirler (TMK. m. 203). Aynı şekilde mal rejimi seçiminin, evlenme başvurusu sırasında evlendirme memurluğuna yazılı bildirim şeklinde de yapılması mümküindür (TMK. m. 205/1). Evlenmeden önce veya sonra yapılan sözleşmenin noterde düzenleme veya onaylama şeklinde düzenlenmesi mümkündür (MK m. 205/I $)^{54}$. Öte yandan böyle bir sözleşmenin sicile kaydı ve ilânı da gerekli değildir ${ }^{55}$.

\section{2) Türk Medeni Kanunu'nda mal rejimleri}

\section{a) Edinilmiş mallara katılma rejimi}

Türk Medeni Kanunu'nun 202 vd. maddelerinde olağan (yasal) mal rejimi olarak "edinilmiş mallara katılma rejimi (Der ordentliche Güterstand der Errungenschaftsbeteiligung =Du régime ordinaire de la participation aux acquêts)" kabul edilmiştir. Isviçre hukukunda 01.01.1988 tarihinde itibaren uygulanan $^{56}$ bu rejim ülkemizde de 01.01.2002 tarihinden itibaren uygulanmaya başlamıştır. Tapu ve Kadastro Genel Müdürlüğü de, yayınladığ mülkiyet halinde malik oldukları taşımma mallarda TMK. m. 232/II hükmü

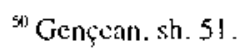

${ }^{51}$ Gerckçe. sh. 386 .

${ }^{32}$ Ayulı yönde görüş için bkz. Özdamar. sh. 297; Gençcan. sh. 51 vd.

${ }^{53}$ Bu konudă geniş bilg̨i için bkz. Başpınar. Veysel; Borç Sözleşmelerinin Kısmî Butlanı. Ankara 1998, sh. 13 vd.

\$4 Bir görijş, bu hükmün, mal rejimi sözleşmesinin sadece düzenteme şcklinde yapılabileceğ́nini öngören Noterlik Kanunu m. 89'u, örtïlü bir şekilde değ̣iştirdiğini savunmaktadır. Bkz. Gençcan, sh. 52.

${ }^{5 s}$ Bu konuda eleştiriler için bkz. Gençcan, sh. 53.

AS 1986 122: SR 210.1. Art. I; BBl 1979 II 1191. Geniş bilgi için bkz. Justiz- und Polizeidepartment (hrsg), Ehe- und Erbrecht. Bern 2000, (www adnin.chicdm) (aşağtda Ehe- und Erbrechi olarak anilacaktur), sh. $20 \mathrm{vd}$.

${ }^{37} \mathrm{Bkz}$. Tapu ve Kadastro Genel Müdürlügü'nün $11,06.2003$ tarih ve 2002/07 sayıł genelgesi. 
gereğince aksine anlaşma bulunmadığı takdirde, eşlerden birinin, diğerinin rızası olmadıkça paylı mülkiyet konusu taşınmazdaki payı üzerinde tasarrufta bulunamayacağını belirtmiştir.

Edinilmiş mallara katılma rejiminde, her bir eşin iki grup malları vardır. Bunlar; "edinilmiş mallar" ve "kişisel mallardır" (TMK. m. 218). Bununla birlikte söz konusu ayrıma "paylı mallar" adı verilen mal grubunu da eklemek gerekir. Bunun anlamı; eşlerden hangisine ait olduğu ispat edilemeyen malların, her iki eşin paylı (müşterek) mülkiyetinde sayılmasıdır (TMK. m. 222/II). Kanun koyucu burada aksi ispat edilebilen adi bir karineye yer vermiştir ${ }^{\text {s8 }}$.

Edinilmiş mallara katılma rejiminde, edinilen mallara hak sahipliği söz konusudur. Hak sahibi olan eşin hakkı kural olarak aynî değil, şahsi bir haktır (TMK. m. 239) ${ }^{59}$. Bu hak niteligłi itibariyle bir alacak hakkıdır.

Edinilmiş mal, her eşin bu mal rejiminin devamı süresince karşılığını vererek elde ettiği malvarlığı değerleridir. Buna göre, bir malın edinilmiş mal sayılması için şu iki şartın gerçekleşmesi gerekir: Söz konusu mal evliliğin devamı sırasında elde edilmiş olmalıdır. Ayrıca bu mal emek karşılığı elde edilmiş olmalıdır. Bir eşin edinilmiş malları TMK. m. 219'da beş bent halinde sayılmıştır. Bunlar; eşin çalışmasının karşıIığı olan edinimler ${ }^{60}$; sosyal güvenlik veya sosyal yardım kurumu ve kuruluşlarının veya personele yardım amacıyla kurulan sandık ve benzerlerinin yaptığ ödemeler; çalışma gücünün kaybı nedeniyle ödenen tazminatlar, kişisel mallarının gelirleri, edinilmiş malların yerine geçen değerlerdir ${ }^{61}$. Eşin kişisel malları ise, TMK. m. 220'de dört bent halinde sayılmıştır. Buna göre bir eşin kişisel malları; kişisel kullanımına yarayan eşya, evlenmeden önce sahip olduğu veya evlenmeden sonra miras veya bağış yoluyla geçen mallar, manevi tazminat alacakları ve kişisel mallarm yerine geçen değerlerdir ${ }^{62}$.

${ }^{58}$ Akıntürk, sh. 148.

${ }^{59}$ Bunun istissnası TMK. m. 240'ta yer almaktadır. Gerçekten de, edinilmiş mallara katılma rẹjiminde katılma alacağı talebi, kural olarak belirli malların tahsisi hakkını kapsamaz. Ancak, eşlerden birinin ölümü halinde sağ kalan eş, birlikte yaşadığı konut üzerinde kendisine, katılma alaçı̆̌na mahsup edilnek üzere. intifa veya sükna hakkı tanınmasını isteyebilir. Să̆ kalan eş böyle bir halde. ev eşyası üzerinde múlkiyet hakkı tanınmasın da talep edebilir.

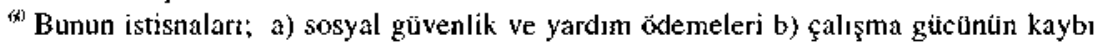
nedeniyle ödenen tazminatlar c) kişisel mallarnn gelirleridir. Bkz. Kılıçoğlu. Rejim, sh. 43 vd.

tii Edinilmiş mallar konusunda geniş bilgi içín bkz. Kuliçoğlu, Yenilikler, sł. 199 vd; Akıntürk, sh. 146 vd; Moroğlu, sh. 26; Özdamar, sh. 325 vd; Gerekçe. sh. 391.

${ }^{62}$ Bkz. Moroğlu, sh. 26; Gerekçe, sh. 391-392; Akıntürk, sh. 147-148; Özdamar, sh. 326 . 
Kanun koyucu, eşlerin yapacakları sözleşme ile bazı kişisel malların da edinilmiş mallara dahil olmasına karar verebilmelerine imkân tanımıştır (TMK. m. 221). Söz konusu hükme göre, eşler, mal rejimi sözleşmesiyle, bir mesleğin icrası veya işletmenin faaliyeti sebebiyle doğan edinilmiş mallara dahil olması gereken malvarlığ değerlerinin kişisel mal sayılacăğmı kabul edebilirler. Yine aynı maddede eşlere, mal rejimi sözleşmesiyle, kişisel malların gelirlerinin edinilmiş mallara dahil olmayacağını karalaştırabilme yetkisi tanınmuştır. Kanımızca bu hükümler, uygulamada özellikle çalışmayan kadın aleyhine kullanılmaya yol açabilecek niteliktedir.

\section{b) Mal ayrılığı}

Bu rejim eski Medeni Kanunda olağan (yasal) mal rejimi idi. Yeni düzenlemede rejimin, ancak seçimlik olarak kararlaştırabileceği kabul edilmiştir. Ayrıca bu rejime Kanun metninde sadece iki madde ayrılmıştır (TMK. m. 242-243). Rejimin esası; her eşin malının kendisine ait olmasıdır. Bu rejimde iki malvarlığı grubu vardır. Bunlar karının mülkiyetindeki mallar ve kocanın mülkiyetindeki mallardır. Iki mal grubunun dışında kalan bir mal bulunmamaktadır. Bu durum eşlerin evlenmeden önce sahip oldukları mallar için geçerli olduğu gibi, evlendikten sonra edindikleri mallar için de geçerlidis ${ }^{6.3}$. Buna göre eşlerden her biri, kanuni smurlar içerisinde kendi mal varlığı üzerinde mülkiyet, yönetim, yararlanma ve tasarruf haklarına bizzat sahiptir $^{64}$.

\section{c) Paylaşmalı mal ayrılı ${ }^{65}$}

Mal ayrılığı ve mal birliği rejiminin aksine, paylaşmalı mal ayrıllı̆̆ rejimi, İsviçre'de olmayan, Avusturya hukukundaki düzenlemeden farkli ${ }^{\text {of }}$ Türk hukukuna özgii bir rejimdir. Bu rejim, edinilmiş mallara katılma rejiminin, uygulanması ve özellikle tasfiyesi strasında yaratacağ̣̆ sakınca ve güçliukleri ${ }^{67}$ ortadan kaldırmayı amaçlamıştır ${ }^{6 . *}$. Bu nedenle, adı geçen rejim.

t.i. Acabey. sh. 50 vd. Ehe- und Erbrechı, sh. 24.

${ }^{\text {tht }}$ Geniş bilg̣i için bkz. Acabcy. sh. 50 yd.

${ }^{45}$ Bu mal rejimi 1998 tasarısinda kanuni mal rejimi olarak kabul edilmiști. Ancak 1994

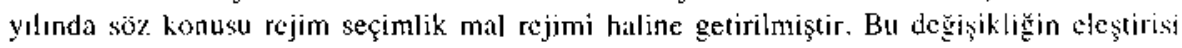
konusunda geniş bilgi için bkz. Akmtürk, sh. 171. Edinilniş malları katılıma rejımi ils paylaşmalı mal ayrılığı rejini arasındaki farkjarla ilgaili ayrıntılı bilụi için bk\%. Kılıçoğ̣lu. Yenilikler, sh. 241 vd.

thi Avusturya hukukunda yer alan paylaşmalı mal rejimi konusunda geneniş bilg̣i için blik. Özdamar. sh. 342 vd.; Zevkliler/Acabey/Gökyayla, sh. 818 vd.

${ }^{n}$ Söz konusu güçlükler konusunda geniş bilgi için bkz. Kılıçoğlu, Öntri. sh. 39 vd. 
bir yönüi ile edinilmiş mallara katılma rejimine, diğer yönü ile ise mal ayrılı̆̆ı rejimine benzemektedir ${ }^{69}$. Adı geçen rejimde eşlerden her biri, evlilik zamanında edindikleri veya kişisel malları üzerinde, kanunun çizdiği sınırlar içinde muilkiyet hakkına sahiptirler. Aynı şekilde her eş kanuni sınırlar içerisinde kendi mallarından dilediği biçimde yararlanabilir ve tasarrufta bulunabilir ${ }^{70}$.

Paylaşmalı mal ayrılığı rejiminin (Gütertrennung mit Zugevinnausgleich) temeli eşlerin mallarının üçe ayrılması esasına dayanmaktadır. Bunlardan ilk sırada "paylaşma konusu mallar" yer alır. Bundan amaç, mülkiyeti eşlerden kime ait olursa olsun rejim sona erip tasfiye edilirken, eşler arasında yarı yarıya paylaşım konusu olan mallardır. İkinci tür mallara "paylaşma dışı mallar" ad verilmektedir. Bu mallar eşlerden yalnız birine ait olan ve diğer eşin üzerinde hiçbir hak sahibi olmadığı haklardır. Meselâ, terzi olan kadının dikiş makinesi, kadına takılan ziynet eşyası bunlardandır ${ }^{71}$. Üçüncü tür mallar ise kanunda "paylı mallar" adı verilen mallardır. Bunlar, her iki eşin paylı mülkiyetinde sayılan mallardır. Kanunda bu tür mallar, "eşlerden hangisine ait olduğu ispat edilemeyen mallar onların paylı mülkiyetinde sayılır" şeklinde ifade edilmiştir (TMK. m. 245/II).

Paylaşmalı mal ayrılı̆̆ı rejiminde paylaştırma konusu mallar kısaca, "aileye özgülenen mallar" diye tanımlanan mallardır. Bunlar ailenin ortak kullanımına ve yararlanmasına (aile konutu, konuttaki ev eşyası, yazlık ev, binek otomobili, deniz motoru, yat, sandal vb.) özgülenmiş olan mallar, ailenin ekonomik geleceğini güvence altına almaya yönelik yatırımlar (menkul kıymetler, tahviller, altın ve dövizler, kira getiren daireler vb.) ve ilk iki sıradaki malların yerine geçen (ikinci bir yazlık, ikinci bir deniz motoru vb.) değerlerdir ${ }^{72}$.

\section{d) Mal ortaklığı rejimi}

Bu rejim gerek eski Medeni Kanunda (eMK. m. 211 vd.) gerek yeni düzenlemede (TMK. m. 256 vd.) seçimlik rejimlerden biri olarak yer almaktadır. Rejimin temeli, ortaklık malları ile her iki eşin kişisel malları

63 Akıntürk, sh. 171; Özdamar. sh. 333; Havutçu. Ayşe; Türk Medeni Kanuıu'nda Kadın-Erkek Eşitliğine Ters Düşen Hükümlet ve Reform Çalışmaları. J̇BD, 1998, S. 1, sh. $10 \mathrm{vd}$.

${ }^{*}$ Özdamar, sh. 333; Akıntïrk, sh. $17 !$.

${ }^{30}$ Bunun istisnaları MK. m. 194 ve 199 hiukümleridir.

"Misal için bkz. Özdamar, sh. 334.

"Geniş bilgi için bkz. Akıntïrk, sh. 173 vd. 
ayrımına dayanır. Bu rejim genel mal ortaklığı rejimi (TMK. m. 257) ve sınırlı mal ortaklı̆̆ı rejimi (TMK. m. 258-259) olmak ïzere ikiye ayrılır. Mal ortaklığı rejimi, ortaklık malları ile eşlerin kişisel mallarını kapsar ( TMK. m. 256). Ortaklık malları, genel mal ortaklığı rejiminde, eşlerin kanun gereği kişisel malları sayılan malları dışındaki bütün mallardan ve gelirlerden oluşur. Bu mal rejiminde hiçbir eş ortaklık malları üzerinde tek başına tasarruf hakkına sahip değildir. Başka bir deyişle, mal ortaklığı rejiminde. ortaklık mallarında elbirliği mülkiyeti (Gesamthandeigentum) söz konusudur (TMK. m. 257/III). Bu mallarda yönetme eski Medeni Kanundan (eMK. m. 212) farklı olarak, kadın erkek eşitliğine uygun bir şekilde, her iki eşe de tanınmıştır (TMK. m. 262-263). Buna karşlık kişisel mallat ise, TMK. m. $260 / I$ hükmüne göre, mal rejimi sözleşmesine, üçüncü kişinin karşılıksız kazandırmasına veya kanunla belirlenir. Meselâ, eşlerden her birinin sadece kişisel kullınımına ayrılmış olan eşyası (karının makyaj malzemesi, kocanın traş takımı) ile manevi tazminat alacakları kanundan dolayı kişisel malıdır (TMK. m. 260/ll). Bu mallarda mülkiyet, yararlanma, yönetim ve tasarruf mal sahibi eşe aittir. Kanun koyucu ortaklık mal lehine aksi ispat edilebilen bir karine de kabul etmiştir. Kanuna göre, bir eşin kişisel malı olduğu ispatlanamayan tüm malvarlığı değerleri ortaklık malı sayılır (TMK. m. 261).

\section{G. Aile konutu}

\section{1) Genel olarak}

Medeni Kanunla aile hukıkunda yapılan önemli değişikliklerden birisi de, aile konutu ile ilgili bulunmaktadir ${ }^{73}$. Eski Medeni Kanun hükümleri arasinda bulunmayan "Aile Konutu (Wohnung der Familine=Logement de la famille)" kavramı Türk hukukunda ilk olarak bu düzenlemede yer almışı ır ${ }^{74}$. Ayrıca eski Kanun hükïmlerinde de değişiklikler yapılmışıır. Her şeyden önce, eMK. m. 152/ll"de yer alan "evin seçimi kocaya aittir" hiikmü değiştirilmiş ve yeni düzenlemede "eşler oturacakları konutu birlikte seçerler" hükmüne yer verilmiştir. (TMK. m. $186 / 1)^{75}$. Öte yandan aile

\footnotetext{
${ }^{73}$ Isviçre hukukunda aile konutu ile ilgili ayrıntılı bilg̨i için bkz. Şipka. Konut, sh. 62 vd; Ehe- und Erbrectit, sh. 11.

${ }^{74}$ Aile konutu ite ilgili olarak bkz. m. 194, 197, 240, 254, 279 ve 652; Ozdamar, sh. 232 vd: Gençcan. sh. 73 vd.; Şıpka, Şükran; Türk Medeni Kanunu’nda Aile Konutu ile ll lgoili İşemlerde Diğer Eşin Rızası (TMK. m. 194) İstanbul 2002.

${ }^{" K o n u ~ i l e ~ i l g ̧ i l i ~ a y t u n t ı l ı ~ b i l g i ~ i c ̧ i n ~ b k z . ~ G e n c ̧ c a n . ~ E v l i l i g ̆ i n, ~ s h . ~ 44, ~ 48 . ~ v d . ~ Z G B . ~ A r t . ~}$ $162^{\prime}$ de de eşlerin aile konutunu birlikte belirleyeckleri hükmü (Die Ehegatten bestimmen gemeinsam die cheliche Wohnung) yer almaktadır. Bu hüküm aym zamanda. Sözleşmeye de uygundur. Zira adı geçen sözleşmede de kadının yerleşim yerini (ikametgahını) seçme konusunda erkek ile eşit hák!ara sahip olduğu vurgulanmıştır (m. 15/b. 4). Söz konusu madde
} 
konutu ile ilgili işlemlerde diğer eşin rızasının alınması zorunluluğu getirilmiştir (TMK. m. 194) ${ }^{76}$. Böylece aile konutu ile ilgili olarak kabul edilen yeni hükümlerle, aile konutu deyim yerinde ise adeta " $\mathrm{z}$ rrh altuna alınmıştır",

2) Kira ile temin edilmiş aile konutu

Aile konutu kira ile temin edilmişse, 01.01 .2002 tarihinden itibaren bir eş, diğer eşin rızası olmadıkça kira sözleşmesini tek başma feshedemez (TMK. m. 194). Böylece eşler, aile konutu konusunda birlikte hareket etmek zorundadır. Bu hükme aykırı işlem, hukuki bakımdan askıda işlem (schwebende Rechtsgeschäft) olup, askıda geçersizlik (schwebende unwirksamkeit) ile sakattır. Kanımızca bu durum sözleşmenin nisbîliği ilkesine ${ }^{78}$ bir istisna teşkil etmektedir.

Aile konutu kira ile temin edilmişse, kira sözleşmesinde kiracı sıfatt bulunmayan eş, kiralayana yapacağı bildirimle (ihbarla) kira sözleşmesinin tarafı haline gelme imkânına sahiptir (TMK. m. 194/IV). Bu bildirim herhangi bir şekle bağlı değildir. Fakat, ispat kolaylığı sağlaması açısından bildirimin yazılı olmasında fayda bulunmaktadır. Söz konusu bildirim, varması gereken bir irade beyan ile yapilır. Zira böyle bir bildirim ancak kiralayana herhangi bir yolla ulaştı̆̆ı anda sonuç doğurur. Bu nedenle, sadece bildirim belgesinin imzalanması yeterli olmayıp, ayrıca kiralayana gönderilmesi (mesela postaya verilmesi) gerekir.

\section{Eşlerden birinin mülkiyetinde olan aile konutu}

Aile konutu eşlerden birinin mülkiyetinde ise malik, diğer eşin rızası olmadıkça, konut üzerindeki hakları sınırlayan hukuki işlemlerde (ipotek

hükmú şöyledir: “Taraf Devletler, kadın ve erkeğe hukuki olarak yerleşme yeri seçme ve nakletmede eşit yasal haklar tanıyacaklardır". Ayrıca bkz. Gerekçe, sh. 379.

${ }^{76}$ Tapu ve Kadaștro Genel Müdürlüğü de, yukarıda tarih ve sayısı verilen genelgesinde, aile konutu ile ilgili olarak tapu kütügüne işlenecek şerh konusunda uygulamadaki tereddütleri giderecek açıklamalar getirmiştir.

$"$ Aile konutu ile ilgilli geniş bilgi için bkz. Słıpka, sh. 112 vd.;Kılıçoğlu, Ahmet; Türk Medeni Kanınu'nda Diğer Eşin Rızasına Bağlı Hukuksal İşiemler ve Yasal Alım Hakkı, Ankara 2002, sh. 6 vd.

Borç ilişkisinin nisbîligìi ilkesi konusunda geniş bilgi iç̧in bkz. Eren, Fikret; Borçlar Hukuku Genel Hükümler, 7. Bası, İstanbul 2001, sh. 18-19; Oğuzman, M. Kemal/Öz, Turgut; Borçlar Hukuku Genel Hükümler, 3. Bası, Istanbu] 2000, sh. 23 vd. 
veya irtifak hakları gibi) bulunamaz. Aynı şekilde malik eş, başkalarma bazı irtifaklar mesefâ, sükna, intifa gibi haklar tanıyamaz ${ }^{79}$.

TMK. m. 194/III'e göre, aile konutu olarak özgülenen (tahsis edilen) taşımmazın maliki olmayan eşe, başka bir imkân daha tanınmıştır. Buna göre, taşıma7.ın maliki olmayan eş, tapu idaresine başvurarak, tapu kütijğune aile konutu şerhinin düşülmesini isteyebilir. Böyle bir şerh ile birlikte üçüncui kişilerin iyiniyeti ortadan kalkar.

Yeni düzenlemeye göre, eşlerin aile ile ilgili yükümlülüklerini yerine getirmesini sağlamak amacıyla tasarruf yetkilerinin kısıtlanması da mümkün hale getirilmiştir (TMK. m. 199) ${ }^{80}$.

Aile konutu konusunda edimilmiş mallara katılma rejiminde. TMK. m. 240 jle, sağ kalan eşe, bazı imkânlar tanınmıştır. Buna göre, eski yaşı̀ntısını sürdürebilmesi için, ölen eşine ait olup, birlikte yaşadıkları konut üzerinde kendisine, intifa veya oturma (sükna) hakkı tanınmasını isteyebilir. Sağ kalan eşin katılma alacağg ${ }_{1}{ }^{\prime \prime}$ yetmediği takdirde, aradaki fark bedel eklenerek karşılanabilir ${ }^{\mathrm{x} \text {. }}$.

Aile konutu ile ilgili olarak, önemli değişikliklerden birisi de, miras brrakanın ölümünde sağ kalan eşin aile konutu ile ilgili talebinde görüilmektedir ${ }^{x_{i}}$. Bu hükme göre, săğ kalan eş, tereke malları arasında ev eşyası veya eşlerin birlikte yaşadıkları konut üzerinde kendisine, miras hakkına mahsuben mülkiyet veya haklı sebeplerin varlığı halinde talep üzerine intifa (Nießbrauch) ya da oturma hakkı (Wohnrecht) tanınmasını isteyebilir (TMK. m. 652/I, II). Bu düzeleme, mirasçılık sıfatına dayanan bir hak temin ettiğinden, eşler arasındaki mal rejimi ne olursa olsun aynen uygulama inkânnna sahiptir ${ }^{\text {kd }}$. Sağg kalan eşin buradaki yetkisi, yasal alım

تMK.m. 194/ll de rızayı temin edemeyen eşe veya haklı bir neden olmaksıı.n kendisine rła herılmeyen eşe. hâkimin müdahalesini isteme yetkisi tanntumı̧̧ır. Hâkim, olayda häklı selxp gormezsc. diğ̣ es eşe işlem yapması için izit vercbilir.

* Isviçre de hoşanmamn sonuçlar arasında yer alan (ZGB. Ati. 121) düzenleme.

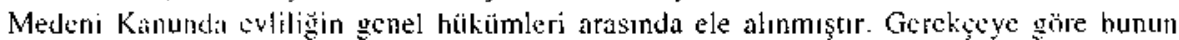
sebebı. Jsviçrèden farklı olarik, ülkemizde kira sözleşmeşine taraf olmayan eşin. evliliğin devam strasinda da mè̆glur olmasıdır. Bkz. Gerekçe sh. 382 .

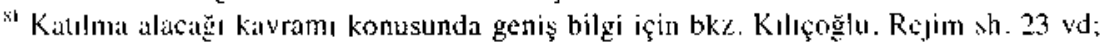
Akintürh. sh 162 -i 164 .

$\therefore$ Diğer mal rejimlerinde aiłe konutu ile ilgili düzenlemeler için bk. MK. 254. 279; Akıntürk, sh. 177.178. 184; Kılıçoğlu. Diğer Eşin, sh. 50. 52.

: Gerçckien de. sağ kalan eşi korumak amaciyla, ZGB Art. 612a hükmü esis alınarak yeni düzenleme yapılmıştır. Bk\%. Gerekçe, sh. 520.

${ }^{4}$ Kılıçoğlı. Diğer Eşin. sh. 53. 
hakkına dayanmaktadır. Kanun koyucunun hükmü sevketmekteki amacr; sağ kalan eşe, ölen eşiyle uzun yıllar birlikte yaşadığı, acı ve tatlı hatıralarla dolu, aile konutunda yaşamaya devam etme imkânı vermektir. Bu nedenle, sağ kalan eş, kendisine tanınan bu imkânı, ölen eşin daha önce yapmış olduğu bir hukuki işlem ile ihlâl edilmesi halinde de kullanabilir ${ }^{8.5}$.

\section{H. Soybağı (Nesep) Hukuku ${ }^{\$ 6}$}

Yeni Medeni Kanun'la getirilen olumlu değişikliklerden birisi de evlilik içi-evlilik dışı soybağı (nesep) ayrımına son verilmesidir ${ }^{87}$. Gerçekten de doktrinde evlilik içi soybağı (sahih nesep)- evlilik dışı soybağı (gayrisahih nesep) ayrımı sürekli eleştirilmekteydi $i^{88}$. İşte kanun koyucu, doktrindeki eleştirileri ve Fransız hukukunda 1972, Alman hukukunda 1970 ve İsviçre hukukunda ise 1978 yılında yapılan değişiklikleri de dikkate alarak, evlilik içi soybağı -evlilik dışı soybă̆ı ayrımına son vermiştir (TMK. m. $282 \mathrm{vd.})^{89}$. Yeni diizenleme ile, bir çocuğun evlilik içinde doğmuş olması ile, evlilik dişında doğmuş olmakla birlikte, sonradan babasıyla soybağı kurulmuş olması durumu arasında hiçbir fark kalmamıştır. Aynca, yeni düzenleme ile

${ }^{85}$ Akıntürk, sh. 166-167; Öztan. sh. 573. Doktrinde Kılıçoğlu tarafından bu konuda verilen misal şöyledir: Meselâ, ölen eş sağlığında yaptığı bir vasiyetname ile aile konutunu belli mal bırakma (muayyen mal vasiyeti) ile kızına veya çok sevdiği yeğenine bırakmış olabiljr. Böyle bir hal. TMK. m. 240 ile sağ kalan eşe sağlanan aynî hakkı ihlâl etmektedir. Bu durumda sał kalan eş. TMK. m. 577 b. 3 (eMK. m. 499, b.3) hükmüne dayanarak, söz konusu vasiyetnamenin TMK. m. 240'a yani hukuka aykırı olduğu iddiasıyla iptal davası açabilir. Bkz. Kılıçoğlu, Rejim, sh. 62.

86 Soybağı (nesep) konusunda geniş bilgi için bkz. Acabey, M. Beşir; Soybağı Kurulması Genel Olarak Sonuçları Özellikle Evlilik Dışında Doğan Çocukların Mirasçılığı (aşağıda Acabey Soybağı olarak antlacaktır). lzmir 2002, sh. 5 vd.: Gençcan, Ömer Uğur; 743 ve 4721 sayılı Türk Medeni Kanununa Göre Soybağıın Kurulması Reddi-Düzeltilmesi İtiraz Davaları ve Soybağının Hükümleri. Ankara 2002, sh. 31 vd; Kılıçoğlu, Yenilikler, sh. 89 vd.

${ }^{87}$ Bu konudaki gerekçede Isviçre'de 1976 yılında yapılan kanan değişikliğine uyum sağlamanın amaçlandığı belirtilmektedir. Bkz. Gerekçe, sh. 415.

* Özellikle evlilik dışı çocuğun, baba bakımından miras hakkının, evlilik içi doğan çocuğun yarısı olmasını öngören hükmünün (eMK. m. 443/Il) Anayasa m. 10, 12, 35, 41'e aykırı bulunarak Anayasa Mahkemesi tarafından iptal edilirken, kararın gerekçesinde yer ałan ifadeler, söz konusu ayrımın kaldırılması gerektiğine işaret etmekteydi. Bkz. Anayasa Mahkemesi'nin 11.9.1987 tarih ve 1/18 saylı kararı (RG. T. 29.3.1988. S. 19769). Bu konuda geniş bỉlgi için bkz. Erman, Hasan; Evlilik Dışı Çocuğun Miraş̧ılığı. IBD. 1988, C. 62, S. 7 9. sh. 437 vd; Koçhisarłoğlu. Cengiz; Salt Biyolojik Babalık ve Yasal Miraş̧ılık, AHFD. 1991-1992, S. 1-4, sh. 142 vd:; Oğuzman. Kemal; Evlilik Dışı Çocukların Babaiarına Mirasçılığı Sorunu Prof. Dr. Jlhan Öztrak'a Armağan. Ankara 1994, sh. 303 vd; Kocayusufpaşaoğlu, Necip; Miras Hukuku, 2. ve 3. Basıłara Ek Kitap, İstanbul 1992, sh. 10 vd.

${ }^{89}$ Geniş bilgi için bkz. Akıntürk, sh. 317 vd. 
eski Kanundan farklı olarak (eMK. m. 295, 297), bir tek babalık davası kabul edilmiştir (TMK. m. 301) ${ }^{\text {(n) }}$.

\section{İ. Evlat Edinme}

Yeni Medeni Kanun'un soybağı hukuku alanında getirdiği önemli değişikliklerden birisi de evlat edinmeye ilişkin diizenlemelerde olmuştur ${ }^{\text {yz }}$. Gerçekten de Türk Medeni Kanunu'nun bu konuya ilişkin düzenlemelerinde pek çok değ̣işiklik yapılmıştır (TMK. m. 305). Ayrıca, eski hükümler arasında bulunmayan yeni bazı düzenlemeler öngörüilmüş (TMK. m. 311); evlat edinmenin şartları önemli ölçüde değiş̧irilmiş ve bu konuda pek çok istisna kabul edilmiştir (TMK. m. 307/II; 310, 311). Mesela, evlat edinme yaşı $35^{\prime}$ ten $^{4.3} 30^{\prime}$ a indirilmiştir (TMK. m. 306/II). Aymı şekilde, eşlerin ancok birlikte evlat edinebilecekleri esası kabul edilmiştir ${ }^{2+4}$. Bunun iki anlamı vardır. Bunlardan birincisi ancak eşler birlikte evlat edinebilirler. Eş olmayan kimseler ise birlikte evlat edinemezler. İkincisi ise eşlerden birinin tek başına evlat edinememesidir. Bundan böyle artık eşler ancak birlikte evlat edinebileceklerdir. (TMK. m. 306/l). Bu nedenle, evli olmayanların birlikte evlat edinebilmeleri mümküin değildir. Yine kural olauak eşlerden birinin tek başına evlat edinmesi kabul edilmemiştir" ${ }^{95}$. Eski Medeni Kanunda yer alan. evlat edinecek kimsenin "nesebi sahih fürunun bulunmamasi" (eMK. 253) hükmü yeni düzenleme ile kaldırılmıştır. Bu nedenle. bir

\footnotetext{
"1" Yeni Medeni Kanundaki soybağı konusunda ayrıntıli bilgi için bk7. Acabey. Soybağı. sh. 5 vd.; Akıntürk. sh. 319 vd.

${ }^{91}$ Bu konuda geniş bilg̨i için bkz. Ruhi. Ahmet Cemal: Türk Hukukunda Evlat Edinme ve Evlat Edinne ile Jlgili Yabancı Malıkeme Kararlarının Türkiye'de Tanıması, 2. Baskı. Ankara 2003, sh. 23 vó; Kılıçoğtu. Yenilikler, sh. 109 vd.

${ }^{92}$ Bkz. Gerekçe, sh. 426 vd.

4.t eMK. m. 253 hükıuti. cvlat edinmede 40 yaş sinırını aramaktaydı. Bu sınır, 16.6.1983 tarih ve 2846 sayılı Kanunta 35 'e indirilmiştir. Bu düzenlemenin eleştirisj için bk\%. Serozan. Rona: Medeni Kanunu Tümüyle Yenilemek Yerinde midir? Yasa Hukuk Dergisi. 1999. S. 9. sh. 1085 .

${ }^{*}$ Kaltçoğlu, Yenilikler, sh. 112, I14 vd. Sözleşmenin 16. maddesinin r bendinde, evlat edinmede kadınların erkeklerle eşit hak ve sorumluluklara sahip olacağı belıtilmiştir.

45 Bunun istisnalsı MK.m. 307/lI'de düzenlenmiştir. Buna göre eşin tek başina evlat edinebilmesi için şu şartların gerçekleşmesi gerekir: a) Eşin otuz yaşın doldurmuş olması. b) diğer eşin ayırt etme güucünden sürekli olarak yoksun bulunması veya c) iki yılı işkın süreden beri ncrede olduğunun bilinmemesi ya da d) mahkeme kararıyla iki yılı aşkın süredir ayrı yaşamaktá olması yüzünden birlikte evlat edinmelerinin mümkủn olmadığını ispat ctmesi. Son üç halden birinin gerçekleşmesi yeterlidir. Geniş bilgi için bkz. Akıntürk, sh. 366; Öztan, sh. 448; Özdamar, sh. 280.
} 
kimseye altsoyu bulunsa dahi, evlat edinme imkânı getirilmiştir ${ }^{96}$. Yeni düzenlemeye göre altsoyu bulunan bir kimse dahi bir veya birden'çok küçüğü evlat edinebilir. Ancak, bunun için küçïğün evlat edinen tarafından bir yıl süreyle bakılmış ve eğitilmiş olması gerekmektedir (TMK. m. 305/I). Buna karşlık, ergin ve kısıtlıların evlat edinilmelerinde ise, evlat edinenin altsoyunun bulunmamasi gerekmektedir (TMK. m. 313/I) ${ }^{97}$.

Eşlerin evlat edinmeleri konusunda alternatifli durum kabul edilmiştir. Birinci duruma göre, eşlerin birlikte evlat edinmeleri için en az beş yıldan beri evli olmaları gerekmektedir. Bu konuda eşlerde yaş sınırı aranmamıştır (TMK. m. 306/II). Zira burada yaş değil, beş yıllık evlilik süresi önemli görüilmüştüir ${ }^{98}$. İkinci durumda, eşlerin her ikisi de otuz yaşını doldurmuş iseler, yine evlat edinebilirler. Burada beş yıllık evlilik süresi gerekli degildir. Bunun yerine evlat edinecek eşlerde yaş şartı dikkate alımmıştır. Bu nedenle, ikinci durumda evlilik yıl değil, otuz yaşm doldurulmuş önemli görülmüştür. Eski Medeni Kanunda olduğu gibi, yeni düzenlemede de, evlat edinenle evlatlık arasında onsekiz yaş farkının bulunması ilkesi kabul edilmiştir (TMK. m. 308/I).

Yeni düzenleme ile evlat edinmede evlatlığın küçük olması ile, ergin veya kısıtlı olması farklı hükümlere tabi kılınmıştır.

\section{J. Koruma amaçlı özgürlüğ̈ün kısitlanması}

Koruma amaçlı özgürlüğün kısıtlanması (Die fürsorgerische Freiheitsentziehung =De la privation de liberté à des fins d'assistance), eski kanunda olmayan, yeni Kanunla getirilmiş bir kurumdur. Kanunda kurumun gerekçesi olarak 1982 Anayasası'nın 19/III hükmiä gösterilmiştir. Kurum düzenlenirken İsviçre Medeni Kanunu'nda 1981 yllında yürürlüğe giren ${ }^{100}$ yeni düzenlemelerden de (ZGB. Art. 397a-397f) yararlanılmıştır ${ }^{101}$. Buna göre, reşit bir kimse, kanundaki sebeplerden birine yakalanmışsa, koruma

${ }^{96}$ Bkz. Gerekçe, sh. 427. Bu konuda geniş bilgi için bkz. Ruhi, A. Cemal; 743 Sayılı Türk Kanunu Medenisi ile 4721 Sayılı Türk Medeni Kanunu'nda Yer Alan Evlat Edinmenin Şekli Şartlarının Mukayeseli OIarak İncelenmesi, AÜEHFD. C. V. S. 1-4, sh. 455 vd.

${ }^{47}$ Ergin ve kısıtlıların evlat edinilmeleri için gerekli diğer şartlat konusunda geniş bilgi için bkz. Gerekçe, sh. 429: Akıntürk 370-371: Özdamar, sh. 279; Öztan, sh. 448.

* Ozdamar, sh. 276.

"9 1982 Anayasası m. 19/III hükmï şöyledir: "... toplum için tehlike bir akıl hastası. uyuşturucu madde veya alkol tutkunu. bir serseri veya hastalık yayabilecek bir kişinin bir müessesede tedavi, eğitim veya ısłabı için kanunda belirtilen esasłara uygun olarak ałınan tedbirierin yerine getirilmesi...halleri dışında kimse hürriyetinden yoksun bırakılama $z$ ".

${ }^{100}$ Bkz. AS 19803135 ; BBI 1977 III I.

[1] Bkz. Gerekçe, sh. 456-458. 
amaçlı olarak özgürlüğü kısıtlanabilir. Bunun için kişisel korunmasının başka şekilde sağlanamaması gerekir. Böyle bir kimse bu amaçla tedavisi, eğitimi veya 1 slahı için elverişli bir kuruma yerleştirilir veya alıkonulabilir. Kanunda, koruma amaçlı özgürlüĭgün kısıtlanması sebepleri olarak "akıl hastalığı, akıl zayıflığı, alkol veya uyuşturucu madde bağgmlılığı, ağır tehlike arzeden bulaşıcı hastahlk veya serserilik ${ }^{102}$ halleri" sayılmıştır ${ }^{103}$. (TMK. m. 432-437).

\section{AILE HUKUKUNDA YAPILMASI GEREKEN DEĞIŞIKLIKLERLE İLGILII ÖNERILERIMIZ}

1) Aile hukuku karşılıklı sevgi ve saygıya dayanan bir alandır. Hukuk kurallarının en az müdahale edebileceği kurum ailedir. Çünkü, aile kurumunda hukuk kurallarından çok, örf ve adet kuralları, görgü kuralları, din kuralları etkili olmaktadır. Bu nedenle, aile kurumuna bukukun müdahalesi en son ve en az olmalıdır. Kanun, bu haliyle söz konusu ilkelere aykırı hükümler içermektedir. Kanımızca bunun telafisi için, Türk Medeni Kanunu'nun aile hukuku ile ilgili düzenlemelerinde aşağıdaki değişiklikler yapılmalıdır:

a) Emeğini ailesine hasreden eş, ayrıca sigorta ettirilmeli ve primleri de aile bütçesinden ödenmelidir. Bununla ilgili düzenleme de sosyal güvenlik kanunlarında yapıImalıdır.

b) Eşler arasında paylaşmalı mal ayrılığı rejimi kabul edildiği takdirde, ailenin ortak kullanımına veya yararlanmasına tahsis edilmiş mallar ile

102 Serserilik kavramının tanımına ne Kanun metninde ne de gerekçede yer verilmiştir. Kimlerin serseri olduğuna somut olayda hâkimin karar vermesi ise, farklı uygulamalara sebep olabilecektir. Oysa 26.04 .1325 (1909) tarihli "Serseri ve Mazanoc-i Sui Eşhas Hakkında Kanun"”un 1. maddesinde "serseri" şu şekilde tanımlanmıştı: "Hiçbir vasıta maişcti bulunmadığı ve çăışmaya kudretli olduğu halde lâakal iki aydan beri bir ģûna. kâr ve kisp veya sanatla meşgul olmayan ve bu müddet zarínda iş bulmak için teşebüsatı lâzimede bulunduğunu dahi ispat edemeyen şurada burada dolaşan kimselere serseri itlak olunur. Çalışmaya muktedir iken teseül’ü vesilei maişet ittihaz edenler dahi setseri addolunurlar”. Metin için bk7. Sicilli Kavanini, C. 16, sh. 17-20. Bu kanun, TBMM. tarafından 11 07.1963 tarih ve 272 sayılı Kanurla yürürlükten kaldırılmıştır (RG. T. 20.07.1963. S. 1 1459). Buna karşılık Kıliçoğlu'na göre, konakładığı veva barındığı yeri belli olmayan, kötü sağ̆lı şartları içinde yaşayan. giyimini. beslenmesini bilmeyen, bütün gün boyunca sokaklarda veya şchirlerarası yolliırda sefit bir şekilde dolașatı. sokkaklarda yatıp kalkan kişiler serseridit. Bkz. Kılıçoğlu. Yenilikler, sh. 146.

${ }^{10: 3}$ Hangi hastalıklann toplum için fehlike arzettiği tıp biliminin konusudur. Bununla birlikte söz konusu hastalıklara AIDS, ilerlemiş verem, kolera, veba misał verilcbilir. Geniş bilgi için bkz. Gerekçe.sh. 457. 
ailenin ekonomik geleceğini güvence altına alan yatırım malları veya bunların ikame değerleri, evliliğin sona ermesi halinde, eşler arasında eşit olarak paylaşılmahdır. Meselâ, eşlerin birlikte yaşadıkları ortak mesken ve burada yer alan eşya, ortak araba, ortak yazlık bunlardan bazılarıdır. Buna karşılık, eşlerin miras yoluyla veya karşılıksız olarak elde ettiği değerler buraya dahil değildir ${ }^{104}$. Zaten bu husus TMK. m. 220/I b. 2'de açıkça kabul edilmiş bulunmaktadır. Eşlerden birine ait olan işyeri veya fabrika, tarımsal işletme, ticari işletme, şirket gibi, ailenin ortak kullanımına tahsis edilmeyen mallarda eşit paylaşım söz konusu olmayacaktır. Ancak, buralardan elde edilip de yine ailenin ortak kullanımına tahsis edilen kazanç veya bununla elde edildikten sonra yine ailenin ortak kullanımına tahsis edilen mallar da paylaşma konusu olacaktır ${ }^{1105}$. Ailenin ortak kullanımına tahsis edilen malın aynen bölünmesi mümkün olmadığı takdirde, diğer eşin payı nakden ödenmeli ve böylece mal eşlerden birine verilmelidir.

2) Kanunda yasal mal rejimi olarak benimsenmiş bulunan edinilmiş mallara katılma sisteminin, akdî bir rejim olarak düzenlenmesi isabetli olabilir. Bu sayede isteyen eşler, yapacakları sözleşme ile aralarında bu sistemi kabul edebilirler.

3) İMK. md. 164'de, eski Medeni Kanun hükümlerinden farklı olarak, mesaisini eve, çocuklara hasreden veya teşebbüste yardımcı olan eşin, diğer eş tarafından kendisine düzenli bir ödemenin yapılmasını talep etme hakkına sahip olduğu ve bu meblağı serbestçe tasarruf edebileceği hükme bał̆lanmıştır. Gerçekten de "serbestçe kullantlabilecek meblağ (Betrag zur freien Verfügung=Montant à libre disposition)" başlığını taşıyan ZGB. Art. 164 'te aynen şu hüküm yer almaktadır:

"Kendisini çocuklartn bakum ve ev işlerine vakfeden veya işinde ve mesleğinde diğerine yardım eden eş, serbestçe tasarruf edebileceği makul miktarda parayt eşinden muntazaman almak hakkina sahiptir.

Bu para miktarmm tespitinde, borçlu eşin kendisine ait gelirlerini, ailenin istikbalini sağlamaktaki ödevlerini işinin ve mesle ğinin gerektirdiği harcantalart nazar itibara almak icap eder"106.

Bu hükümle, kadının serbestçe kullanabileceği makûl miktarda bir parayı elde etmesine imkân sağlanmaktadıı ${ }^{107}$. Ayrıca, bir eşin, ailenin

${ }^{121}$ Kılıçoğlu, sh. 49-50.

${ }^{105}$ Bkz. Medeni Kanun 1998 Tasarısı, m. 224 gerekçesi (sh. 105).

${ }^{1106}$ Madde hakkında geniş bilgi için bkz. Özer, Ahmet; İviçre Aile Rejiminde Son Gelişmeler. Yargıtay Dergisi, 1988, Sayı 1-2, sh. 118. 
geçimi için gerekli katkının çok üstünde bir miktarda eşinin işyerinde veya mesleğini icrada yardımcı olması halinde, makul bir tazminata hak kazanmalıdır. Yine bir eş, gelirleri ve serveti ile ailenin geçimine, borçlu olduğundan çok daha fazla miktarda katkı sağlarsa, aynı şekilde tazminat hakkı doğgnalıdır. İsviçre Medeni Kanunu m. 165'in yeni metninde böyle bir tazminata imkân tanınmaktadır. Bu hükümle, kocanın ticarethanesinde, muayenehanesinde veya avukatlık bürosunda önemli çalışmalar yapan kadını hedef almakta ve onun bir aile yardımına bağlanmasın amaçlamaktadır. Gerçekte de "bir eşin olağanüstü kattkısınm düzenlendiği (ausserordentliche Beiträge eines Ehegatten= contribution extraordinaire d'un époux)" ZGB. Art. 165 hükmü şöyledir:

"Bir eşin ailenin geçimi için gerekli katkınn çok üstïnde eşinin teşebbüs ve mesleğine yardmuct olması halinde. muhik bir tazminata hak kazantr.

Bir eş, gelirleri ve serveti ile ailenin geçintine, borçlu olduğundan çok daha fazla miktarda katkı sağlarsa, aym şekilde tazminata hak kazantr.

Karı kocadan biri bu olağaniistï katkısm, bir iş, borç veya şirket sözleşmesi gereğince veya başka bir hukuki ilişki nedeniyle sağlamışsa. tazminat talebinde bulunamaz"

ZGB. Art. $165^{`}$ te yer alan söz konusu hükme benzer bir düzenleme Türk Medeni Kanunu'nda meveut değildir. Bu nedenle. Kanunda yapılacak değişiklikle, İsviçre Medeni Kanunu m. 164 ve 165 'te getirilen sistem aynen bizde de uygulanmalıdır. Üstelik İsviçre'de de aynı mal rejimi yürürlüktedir.

\section{SONUÇ}

Yeni Türk Medeni Kanunu ile aile hukukunda pek çok önemli değişiklikler getirilmiştir. Bu değișiklikler genel bir değerlendirilneye tabi tutulduğınỏa özellikle kadının durumunun iyileştirilmesinin amaçlandığı görülmektedir. Bunlardan en önemlisi; edinilmiş mallara katılma rejiminin, yeni ve yasal mal rejimi olarak kabul edilmesidir. Ancak, bu mal rejiminde bazı düzenlemelerin, kadının korunması genel amacına aykırı olduğunu söylemek mümkündür. Özellikle, edinilmiş mallara katılma rejiminde TMK. m. 221 dïzenlemesi böyle bir hükümdür. Yine, eşlerin artık değere katılma oranını değş̧tirebilmeleri; bazı kişisel malların gelirlerinin, edinilmiş mallara

${ }^{107}$ Özer, sh. 125.

${ }^{\text {tet }}$ Bkz. Özer, sh. 118, 125. 
dahil olmayacağını kararlaştırabilmeleri (TMK. m. 237/l) genel amaca aykırı ilk göze çarpan hükümlerdir. Söz konusu hükümler, özellikle çalışmayan kadın aleyhine düzenlemelerdir.

Yeni Kanun hazırlanırken evde çocuklarına bakan veya eşinin yanında veya işyerinde çalışan kadınlar için, bazı ek koruma önlemleri getirmek mümkuindü. Bu düzenlemeler yapılırken ZGB. Art. 164 ve 165 hükmü örnek alınabilirdi. Bunlar yapılmadığı takdirde kadını, özellikle çalışmayan, fakat evde çocukların bakım ve egitimine yardımcı olan kadını korumak mümkün görünmemektedir. Isviçre'deki son değişikliklerin dikkate alındığı iddia edilen ${ }^{10 \%}$ Kanun, bu haliyle çağın ihtiyaç ve taleplerinin çok gerisinde kalmaktadır.

Ayrıca, yeni Medeni Kanun hazırlanırken, mukayeseli hukukta aile hukukuna ilişkin yapılan değişiklik ve yeniliklerin, Avrupa Birliği'nin ortak bir Medeni Kanun hazırlama çalıșmaları ${ }^{110}$ da dikkate alındığında, Birlik mevzuatı ile Türk mevzuatının uyumu da daha kısa zamanda gerçekleştirilmiş olur.

${ }^{109}$ Gerekçe, sh. 286, 287. 299.

${ }^{110}$ Bu konuda geniş bilgi için bkz. European Parliament; The private law systems in the EU: Discrimination on grounds of nationality and the need for European Civil Code, Luxembourg 2000 . 